\title{
維持管理を考慮した防波堤ケーソン前壁の 耐衝撃設計に関する検討
}

\author{
川端 雄一郎 1 ・加藤 絵万 2 ・岩波 光保 ${ }^{3}$ \\ 1正会員 港湾空港技術研究所 構造研究チーム（†239-0826 神奈川県横須賀市長瀬3-1-1） \\ E-mail: kawabata-y@pari.go.jp \\ 2正会員 港湾空港技術研究所 構造研究チーム（†239-0826 神奈川県横須賀市長瀬3-1-1） \\ E-mail: katoh-e@pari.go.jp \\ 3正会員 東京工業大学大学院 理工学研究科（干152-8552 東京都目黒区大岡山2-12-1 M1-21） \\ E-mail: iwamami@cv.titech.ac.jp
}

\begin{abstract}
消波ブロック被覆堤では，消波ブロックがケーソン前壁に繰り返し衝突し，穴あきなどの局 部破壊が発生する場合があり，このような局部破壊に対する耐衝撃設計・照査方法の確立が不 可欠である.また，防波堤新設時において，ケーソンの耐衝撃性を向上させることを目的とし た予防対策を実施する上では，ライフサイクルコスト（LCC）を検討することが肝要である. 本論は，防波堤ケーソンについて，新設時の予防対策がLCC縮減の観点から有利となる条件を 明らかにすることを目的とした。具体的には，局部破壊を生じた防波堤ケーソンを対象として， 数種類の補修シナリオに対して補修費用を試算するとともに, 予防対策を講じた場合の対策費 用を試算し，それらの比較により，LCC縮減の観点からの予防対策の有効性を示した.
\end{abstract}

Key Words : breakwater, caisson, local failure, preventive measures, life-cycle cost

\section{1. はじめに}

消波ブロック被覆堤では，消波ブロックがケーソン前 壁に繰り返し衝突し，穴あきなどの局部破壊が発生する 場合がある ${ }^{1)}$. ケーソン前壁の局部破壊は中詰材の流出 を招き，堤体重量を減少させるため，滑動等に至るケー スもある，港内の安全性を十分に確保寸るためには，消 波ブロックの繰返し衝突によるケーソン前壁の局部破壊 を未然に防ぐことが必要である.このような背景の中， ケーソン前壁の局部破壊に関する設計・照査法について, 「耐衝撃性に優れる防波堤ケーソンの設計マニュアル

(案)」（以下，耐衝撃設計マニュアル（案））点が提 案されている. 一方, 設計でケーソン前壁の而衝撃性を 向上させることを目的とした対策の実施の可否を判断す るためには，ライフサイクルコスト（LCC）縮減の観点 から検討することが肝要である。しかし，䂆防対策の有 効性は，防波堤全体における局部破壊の発生状況に強く 影響される．したがって，予防対策が LCC 縮減の観点 から有利になる条件を明らかにすることは有用である.

本研究では, ケーソン新設時における予防対策の要否 の判断に資するため, 新設の防波堤ケーソンにおいて,
予防対策がLCCの観点から有利となる条件を明らかにす ることを目的とした．具体的には，局部破壊が発生した 防波堤ケーソンを対象として, 数種類の補修シナリオに 対する費用を試算するとともに，予防対策を講じた場合 の対策費用を試算し，それらの比較により，LCC縮减の 観点から予防対策が有利となる局部破壊の発生率を算定 した. なお，本論で取り扱う発生率は「対象函数に対す る局部破壊発生函数の割合」と定義した。ただし，既往 の事例では局部破壞発生時の作用が不明である，局部破 壊が発生する波浪条件等については今後の課題としたい.

\section{2. 検討概要}

\section{(1) 対象施設}

対象施設として，実際に局部破壊が発生した防波堤を 2施設（防波堤I，防波堤II）選定した. 図-1に標準断面 図を，表-1に設計条件を示す．防波堤I， IIいずれも $H_{\text {max }}$ が13.0 m以上である. また，防波堤 $\mathrm{I}$ で 80 型，防波堤Iで 64 型，と大型の消波ブロックが使用されている．防波 堤䏠よびாについて, 局部破壊の発見時における発生率 を算定した結果，それぞれ $11 \%$ （供用9年後調査）， 


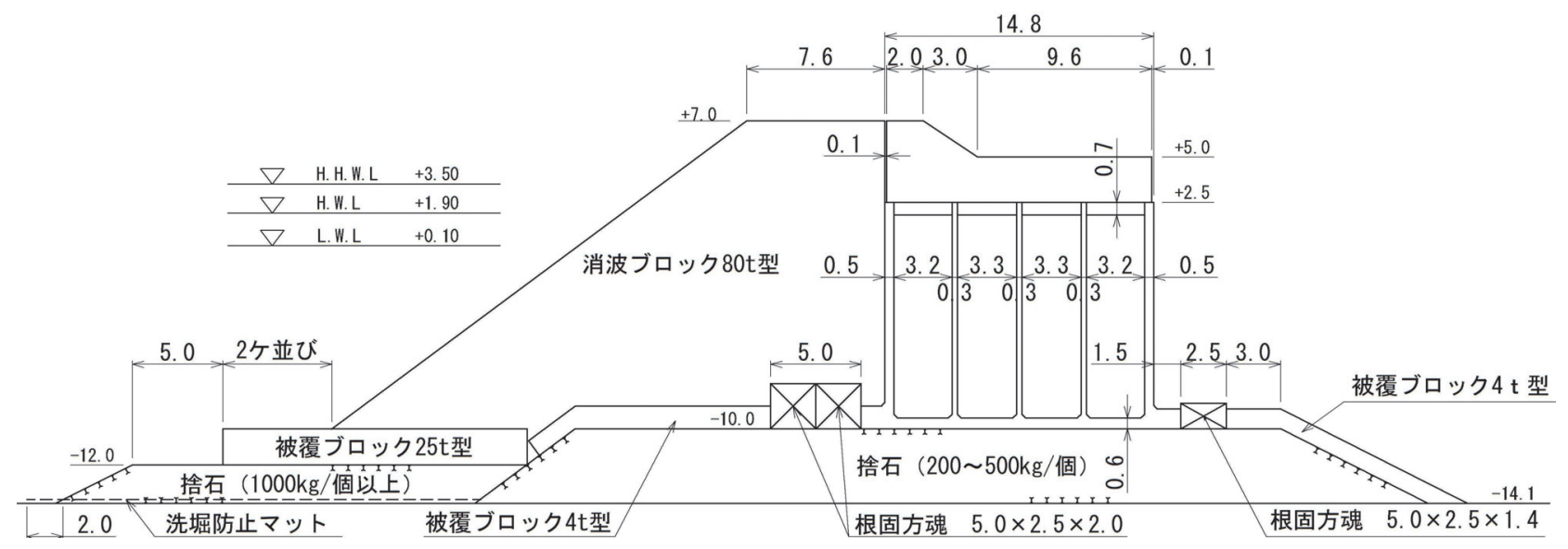

(a) 防波堤 I

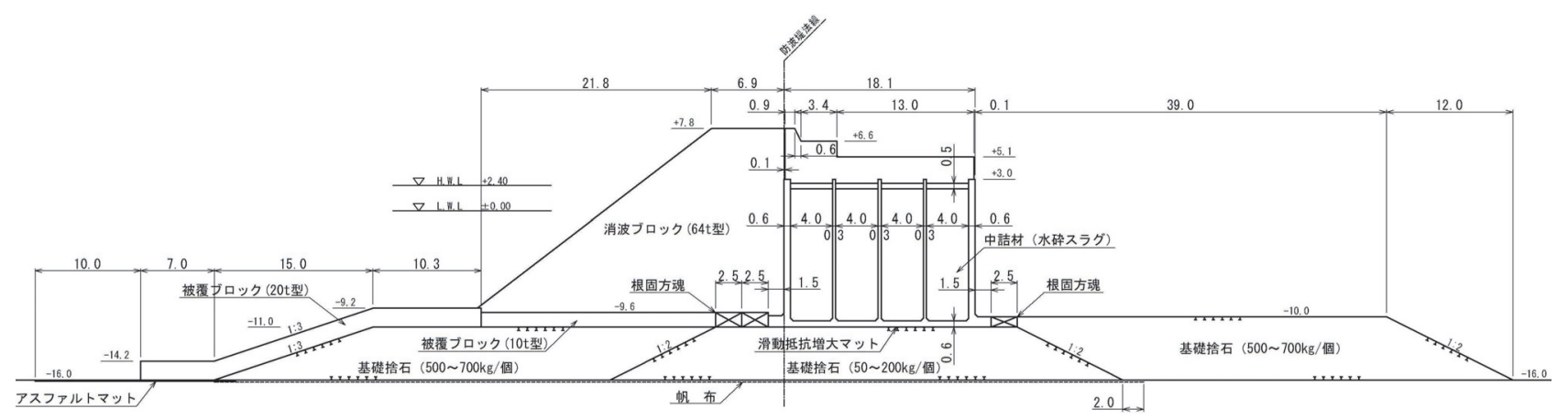

(b) 防波堤 II

図-1 標淮断面図 (単位 : m)

表-1 設計条件および照査結果

\begin{tabular}{|c|c|c|c|}
\hline & & 防波堤 I & 防波堤 II \\
\hline \multirow{3}{*}{ 自然条件 } & H.W.L. & D.L. $+1.90 \mathrm{~m}$ & D.L. $+2.40 \mathrm{~m}$ \\
\hline & L.W.L. & D.L. $+0.10 \mathrm{~m}$ & D.L. $\pm 0.00 \mathrm{~m}$ \\
\hline & 砕波時の波速 C & $13.14 \mathrm{~m} / \mathrm{s}$ & $13.44 \mathrm{~m} / \mathrm{s}$ \\
\hline \multirow{8}{*}{$\begin{array}{c}\text { ケーソン前壁 } \\
\text { の構造 }\end{array}$} & 支間長 $l$ & $4.83 \mathrm{~m}$ & $5.30 \mathrm{~m}$ \\
\hline & 版厚 $h$ & $0.50 \mathrm{~m}$ & $0.50 \mathrm{~m}$ \\
\hline & 鉄筋中心からコンクリート表面までの最短距離 & 港外側 $80 \mathrm{~mm}$ 港内側 $60 \mathrm{~mm}$ & 港外側 $80 \mathrm{~mm}$ 港内側 $60 \mathrm{~mm}$ \\
\hline & コンクリートの設計基淮強度 $f_{d k}$ & $30 \mathrm{~N} / \mathrm{mm}^{2}$ & $24 \mathrm{~N} / \mathrm{mm}^{2}$ \\
\hline & コンクリートのヤング係数 $E_{c}$ & $28 \mathrm{kN} / \mathrm{mm}^{2}$ & $25 \mathrm{kN} / \mathrm{mm}^{2}$ \\
\hline & 粗骨材の最大寸法 $G_{m a x}$ & $20 \mathrm{~mm}$ & $20 \mathrm{~mm}$ \\
\hline & 鉄筋の引張降伏強度の特性值 $f_{y k}$ & $345 \mathrm{~N} / \mathrm{mm}^{2}$ & $345 \mathrm{~N} / \mathrm{mm}^{2}$ \\
\hline & 鉄筋のヤング係数 $E_{s}$ & $200 \mathrm{kN} / \mathrm{mm}^{2}$ & $200 \mathrm{kN} / \mathrm{mm}^{2}$ \\
\hline \multirow{3}{*}{ 消波ブロック } & 消波ブロック質量 $M$ & $80,500 \mathrm{~kg}$ & $58,880 \mathrm{~kg}$ \\
\hline & 脚の先端半径 $r$ & $0.55 \mathrm{~m}$ & $0.495 \mathrm{~m}$ \\
\hline & 消波ブロック高さH & $5.0 \mathrm{~m}$ & $4.505 \mathrm{~m}$ \\
\hline 照査 & 破壊衝突回数 $N_{u}$ & 2 回 $<N_{e}=150$ 回 (N.G) & 5 回 < $N_{e}=150$ 回 (N.G.) \\
\hline
\end{tabular}

6.4\%（供用30年後調査）であつた.

耐衝撃設計マニュアル (案) 2)に基づいて照査した結 果を表-1に示す. 防波堤I， II ももに，設計衝突回数 $\left(N_{e}\right)$ に対して, 破壊衝突回数 $\left(N_{u}\right)$ が大幅に下回り, 照査を満足しない結果となった。

\section{（2）対策費用の算定方法}

既往の検討から，ケーソン前壁の而衝撃性向上には, 短綫維補強コンクリートの使用, 鉄筋比の増加, 版厚の 増加，の 3 つの予防対策が有効である ${ }^{2)}$. 本論では表-2 に示す予防対策ケースについて，照査を満足するよう対 策を選定した. すなわち, 照査を満足する条件として, 
短繊維補強コンクリート（対策ケース 1）の場合には短 繊維混入率，鉄筋比の増加（対策ケース 2）の場合には 鉄筋比, 版厚の増加（対策ケース 3）の場合には版厚, をそれぞれ求めた．なお，対策は而衝撃設計マニュアル

(案) ${ }^{2)}$ に基づき，ケーソン前壁の久が対象である.

ここで，通常ケーソンの配筋設計では，D13〜D25の 範囲のものが使用される．通常，D25よりも大きな径の 鉄筋を用いる場合には，鉄筋の曲げ加工が煩䧱になり， ガス圧接等も必要となる．本論では，施工の観点から鉄 筋の最大径をD25，最小の鉄筋間隔を $100 \mathrm{~mm}$ とした.

それぞれの対策について，対策の実施によってケーソ ン1函の製作に加算される費用 $C_{p c}$ を算定した，なお，短 繊維補強コンクリートにかかる費用については材料費の みを計上したものであり，それに要する人件費，短䋊維 使用に伴って発生するアジテータ車の洗浄費等の工費に ついては考慮していない，また，費用算定における数量 等は参考文献をを参照していただきたい.

\section{（3）補修シナリオの設定と補修費用の算定方法}

局部破壊が発生したケーソンの補修シナリオを表-3 の 3 ケース設定した。 補修ケース A，Bでは，ケーソン 前壁に局部破壞が生じているものの，堤体滑動が生じて いない場合を，補修ケース C では，ケーソンの局部破 壊によって堤体滑動が生じた場合を想定した。

補修ケース A では，消波ブロックの撤去後に前壁の 破壊箇所を型枠で塞ぎ，上部コンクリートに削孔した穴 から隔室に水中コンクリートを打設するシナリオとした. 施工手順は，(1)消波ブロックの撤去，(2)上部コンクリー トの削孔，(3)港外側の隔室 1室中の中詰材を全て撤去, (4)ケーソン前壁に前面から型枠を設置, (5)水中コンクリ 一トの打設，(6)型枠の除去，(7)上部工削孔部の埋戻し， 8)消波ブロックの復旧，である. ケーソン前壁の局部破 壊は，ケーソン 1 函あたり 1 箇所，L.W.L.から消波ブロ ック 1 個分の高さで港外側の隔室 1 室の夕に生じたもの とした．消波ブロックの撤去範囲は，破壞発生箇所の下 側では前壁厚分，破壊箇所の防波堤延長方向両側では 1 個分の消波ブロックを撤去するものとした．撤去勾配は， 消波工の法勾配，断面方向は直切りを想定した（図-2）。 上部コンクリートの削孔径は $\phi 400 \mathrm{~mm}$ とし, 中詰材の撤 去は $\$ 200 \mathrm{~mm}$ のサンドポンプで行うものとした.

補修ケース B では, 上部工および蓋コンクリートを 撤去した後に, 隔室内部から型枠を設置し, 港外側の隔 室に水中コンクリートを打設するシナリオを想定した. 施工手順は，(1)上部工および蓋コンクリートの撤去，(2) 局部破壊が発生した隔室内の全ての中詰材をグラブによ り撤去，(3)隔室内部に型枠を設置，(4)隔室に水中コンク リートを充填，(5)蓋コンクリートおよび上部工の復旧， である．消波ブロックによる破損個所は補修ケース A
表-2 ケーソン前壁の予防対策ケース

\begin{tabular}{l|l}
\hline 対策ケース 1 & 短繊維補強コンクリートの使用 \\
\hline 対策ケース 2 & 鉄筋比の増加 \\
\hline 対策ケース 3 & 版厚の増加 \\
\hline
\end{tabular}

表-3 局部破壊が発生したケーソンの補修シナリオ

\begin{tabular}{|c|c|c|c|}
\hline 補修ケース A & \multicolumn{3}{|c|}{$\begin{array}{l}\text { 消波ブロック撤去後隔室にコンクリー } \\
\text { 卜充填 }\end{array}$} \\
\hline 補修ケース B & \multicolumn{3}{|c|}{$\begin{array}{l}\text { 上部コンクリート撤去後隔室にコンク } \\
\text { リート充填 }\end{array}$} \\
\hline 補修ケース C & \multicolumn{3}{|c|}{$\begin{array}{l}\text { 滑動したケーソンの中詰材除去して再 } \\
\text { 度据付後, 隔室にコンクリート充填 } \\
\end{array}$} \\
\hline & 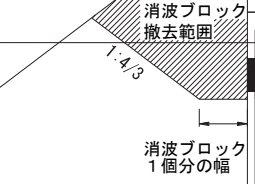 & 椇傷箘所 & \\
\hline
\end{tabular}

a) 断面図

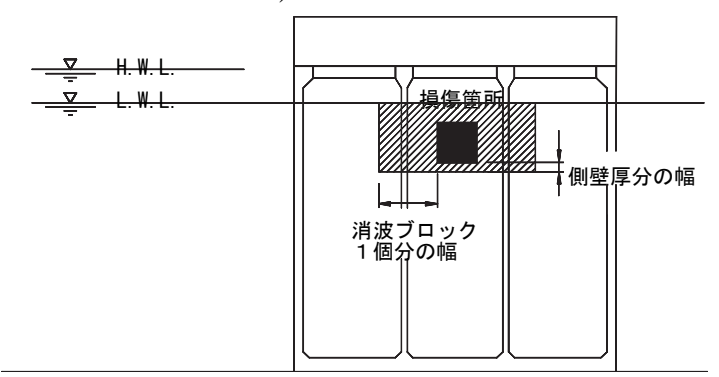

b) 正面図

図-2 消波ブロック撤去範囲（補修ケース A）

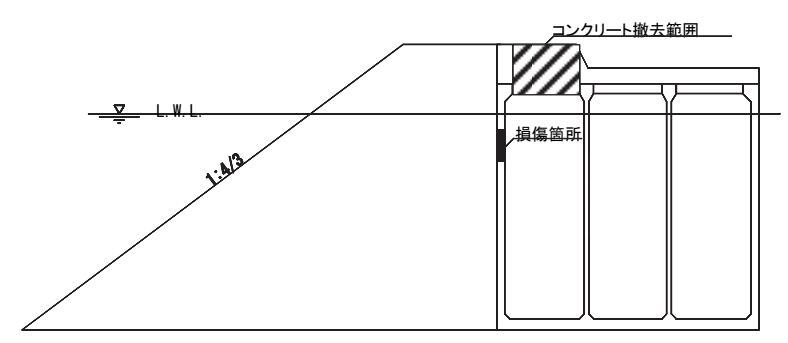

図-3 上部コンクリート撤去範囲（補修ケース B）

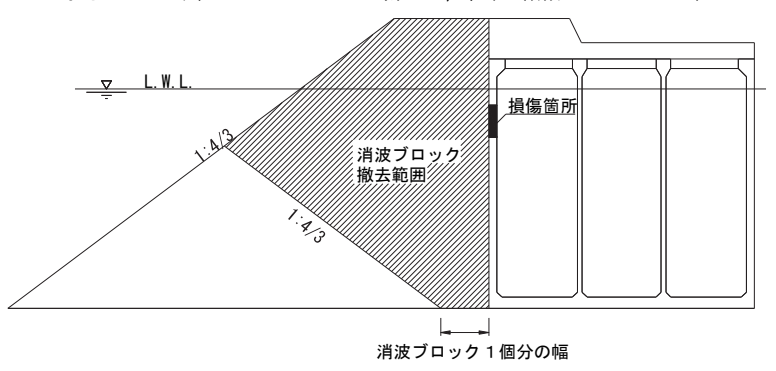

図-4 消波ブロック撤去範囲（補修ケース C)

と同様とした．また，上部工および蓋コンクリートの撤 去範囲は隔室 1 室分（図-3）とした.

補修ケース C では，局部破壊によりケーソンの自重 
表-4 ケーソン前壁の予防対策ケース

\begin{tabular}{|c|c|c|c|c|c|c|}
\hline & \multicolumn{3}{|c|}{ 無対策 } & 対策ケース 1 & 対策ケース 2 & 対策ケース 3 \\
\hline & $\begin{array}{c}\text { 短繊維混入率 } \\
\text { (\%) }\end{array}$ & $\begin{array}{c}\text { 平均引張鉄筋比 } \\
\text { (\%) }\end{array}$ & $\begin{array}{c}\text { 版厚 } \\
\text { (m) }\end{array}$ & $\begin{array}{c}\text { 短繊維混入率 } \\
\text { (\%) }\end{array}$ & $\begin{array}{c}\text { 平均引張鉄筋比 } \\
(\%)\end{array}$ & $\begin{array}{c}\text { 版厚 } \\
\text { (m) }\end{array}$ \\
\hline 防波堤 I & 0 & 0.19 & 0.5 & 1.25 & $\times(1.19)$ & 2.30 \\
\hline 防波堤 II & 0 & 0.15 & 0.5 & 1.03 & 0.63 & 1.85 \\
\hline
\end{tabular}

表-5 対策費用

\begin{tabular}{c|l|c|c}
\hline \multicolumn{2}{c|}{ 対策ケース } & $\begin{array}{c}\text { 防波堤 I } \\
\text { (万円/函) }\end{array}$ & $\begin{array}{c}\text { 防波堤 II } \\
\text { (万円/函) }\end{array}$ \\
\hline ケース 1 & 短繊維補強コンクリートの使用 & 473 & 572 \\
\hline ケース 2 & 鉄筋比の増加 & $\times(129)$ & 152 \\
\hline ケース 3 & 版厚の増加 & 584 & 514 \\
\hline ケース 2+3 & 鉄筋比の増加, 版厚の増加 & 172 & - \\
\hline
\end{tabular}

表-6＼cjkstart各補修シナリオの補修費用

\begin{tabular}{c|l|c|c}
\hline \multicolumn{2}{c|}{$\begin{array}{c}\text { 補修ケース } \\
\text { ケース A }\end{array}$} & $\begin{array}{c}\text { 防波堤 I } \\
\text { (万円/函) }\end{array}$ & $\begin{array}{c}\text { 防波堤 II } \\
\text { (万円/函) }\end{array}$ \\
\hline ケース B & 上部コンクリート撤去後隔室に中詰コンクリート充填 & 1,084 & 1,076 \\
\hline ケース C & 中詰材を除去して再度据付後, 隔室に中詰コンクリート充填 & 1,316 & 1,966 \\
\hline
\end{tabular}

が小さくなることでケーソンが滑動し，さらに一部の消 波ブロックが散乱した状況とした. したがって，ケーソ ンを据え直し，港外側の隔室に水中コンクリートを打設 するシナリオを想定した．施工手順は，(1)消波ブロック の撤去，(2)上部工の全撤去，(3)中詰材の全撤去，(4)ケ一 ソンの据直し，5港外側の隔室に水中コンクリートを充 填, 6)その他の隔室に中詰材を充填, (7)蓋コンクリート および上部工の復旧，である。滑動したケーソンは基礎 マウンド上に残存しており，転倒はしていないものとし た.また，ケーソンの滑動量は消波工 1 個分とした．消 波ブロックの撤去範囲は図-4に示す通りとした.

設定した補修シナリオについて，ケーソン 1 函に対す る補修費用 $C_{c c}$ を算定した．なお，費用算定における数 量等は参考文献 2)を参照していただきたい.

\section{4. 結果および考察}

\section{（1）照査を満足する予防対策内容とその対策費用}

表-4に防波堤拉よびாにおけるケーソン前壁の局部破 壊に対する照査を満足する対策内容を示す，対策午一ス 1では，コンクリートの短繊維混入率を1.0\%強とするこ とで照査を満足した．短䋊維補強コンクリートでは，短 繊維混入率が高い場合には施工性の悪化が懸念される. 既報了によれば，短繊維混入率1.0\%までは通常のコンク リートと同等の施工性を有するとされているが，現状で は1.0\%以上の短繊維混入率については十分な知見がな いため，短繊維補強コンクリートを使用するにあたって
は施工性の検討を十分に行う必要がある。

対策ケース 2 にいて，防波堤Iでは平均引張鉄筋比を 1.19 \%としても照査を満足しなかった。 これは，施工性 の観点からD25の鉄筋を100 mmピッチで使用することを 上限としたためである。この場合，他の対策と併用する

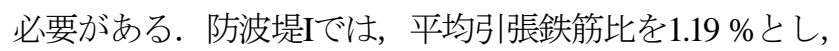
さらに版厚を0.6 mとすることで，照査を満足した．防 波堤IIでは，版厚を変えず，鉄筋比 0.63 \%とすることで 照査を満足した.

対策ケース3について，防波堤I，IIでそれぞれ版厚2.30 m, 1.85 mとすることで照査を満足した. 一般的なケー ソンの版厚約 $0.5 \mathrm{~m}$ と比較すると相当に大きい. この場 合，ケーソンの浮遊が困難となることが推測され，事前 の施工性の検討が不可欠である.

表-5に防波堤I，Iの予防対策費用を示す。防波堤匹に 着目すると，対策ケース 2 が最も安価であり，他2ケース の1/3以下であった。ケース 1 ケース3はほぼ同等の費 用と考えられたが，ケース1においては材料費の夕計上 しているため, ケース 1 が最も高価な対策と判断するこ とができる. 防波堤Iでは，ケース2で照査を満足できず, 費用を算定できなかった。 なお，鉄筋比の上限值1.19\% における対策費用は129万円/函であった。この時，版厚 を0.6 mとして照査を満足した場合，約172万円/函となり， 他2ケースよりも安価であった. ケース1とケース3を比 較すると，ケース1の方が安価になった。

以上より，ケーソン前壁の耐衝撃性を向上させる場合, 施工性を悪化させない範囲で鉄筋比を増加させ，鉄筋比 
の増加のみで照査を満足しない場合，他の予防対策と併 用することが，LCC低減に有効と考えられる．また，短 繊維補強コンクリートの使用もしくは版厚の増加を選択 する場合には，構造条件や作用条件によって施工費用の 観点からの優劣が異なるため，事前にLCC低減が可能な 工法を検討することが望まれる．特に，版厚の増加を選 択する場合，それに伴って自重バランスが異なるため, 基本設計での再検討が必要になるなど，設計の手戻りが 生じる可能性がある.したがって，設計時において，施 工上の制約条件を十分に考慮しながら，維持管理に配慮 して予防対策を選択することが重要である.

\section{（2）各補修シナリオの補修費用}

表-6 に防波堤 I，II の補修費用を示す．補修工法とし て, ケース A が最も安価となり, 次いでケース B とな った. これらはケーソンが滑動していないことを想定し ているため, 比較的安価に補修が可能であった. 一方, ケーソンが滑動することを想定したケース C では，ケ 一ス A，Bよりも 5〜10 倍近くの費用となった．つまり， 前壁に穴あきの発生を確認した場合，堤体滑動が生じる 前に補修を講じることが LCC 縮減の観点から有利であ る．なお，ケース C の補修費用は補修に要する費用の
みを算定しており, 港内の静穏度の確保が困難になるこ とで生じる間接的な損失については考慮していない.

\section{（3）LCC縮減の観点からの予防対策の有効性の検討}

本研究では，各補修シナリオの補修費用と予防対策に 必要な費用を比較し，LCC 縮減の観点から予防対策が 有利となる発生率を算定した。ここで，発生率の設定に は波浪条件等を考慮した上で設定すべきであるが，現状 ではその設定法は構築されていない，したがって，実務 では，対象防波堤の過去の事例や類似の防波堤の事例か ら発生率を設定することが望ましい.

対象防波堤のケーソン $n$ 函のうち，防波堤の局部破壊 を生じる函数は， $n$ 函に発生率 $P_{t}$ を乗じることで求める ことができる.すなわち，局部破壊の発生函数は $n P_{t}$ で ある．局部破壊の発生函数に補修費用 $C_{c}$ を乗じること で，対象防波堤に生じる補修費用は $n P_{t} C_{c c}$ となる.した がって，発生率を考慮した防波堤の総補修費用を期待補 修費用と定義すると，期待補修費用は $C_{c}=n P_{t} C_{c c}$ で求め

\section{ることができる.}

対象防波堤の耐衝撃性向上のための対策費用について は，対象ケーソン $n$ 函全てに対して予防対策を講じるこ とを前提となる. 予防対策を行った前壁は供用中破壊し

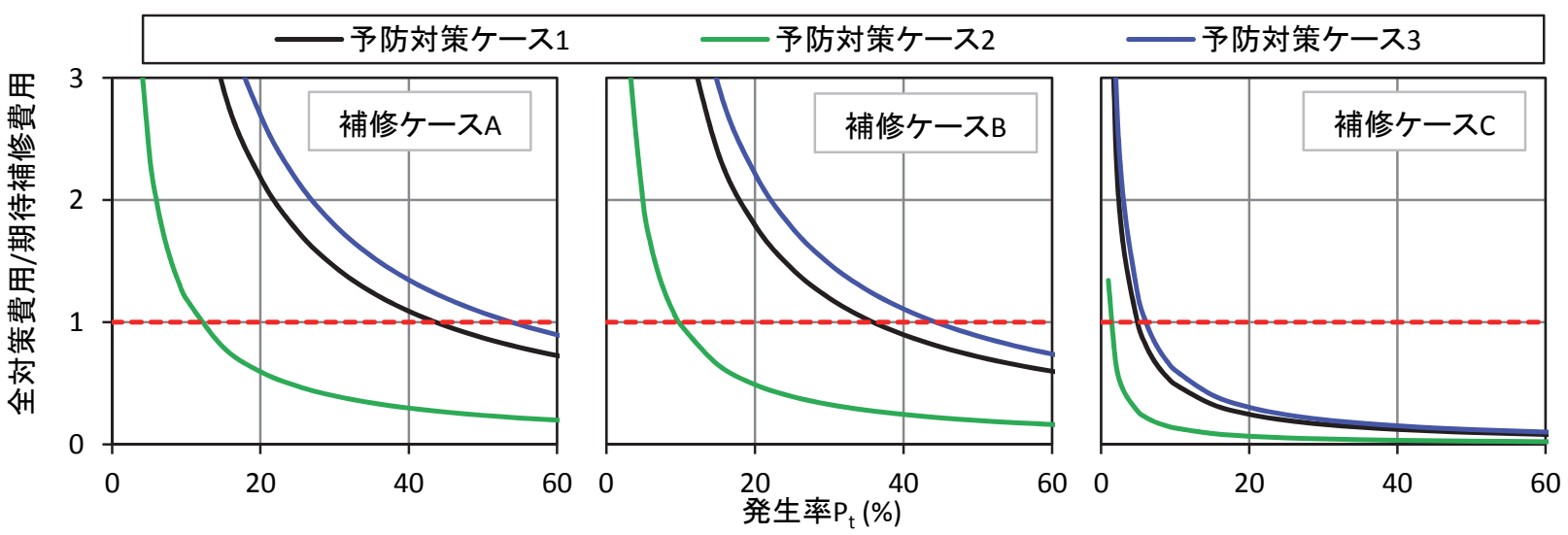

(a) 防波堤 I

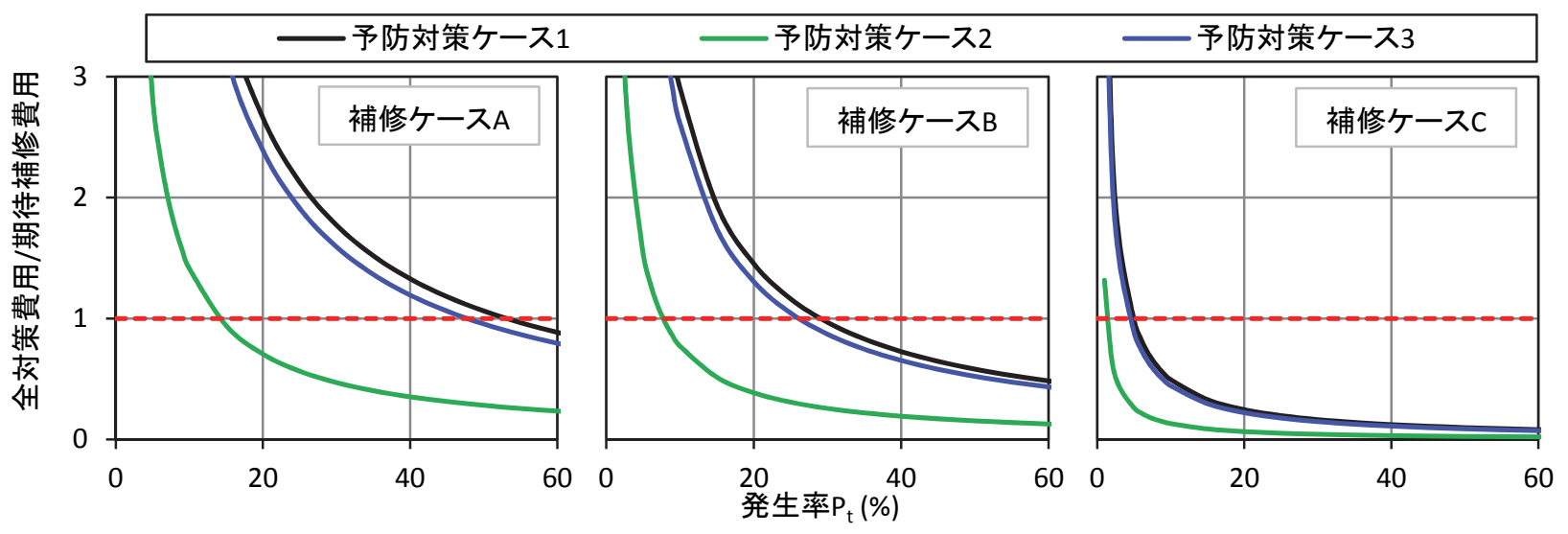

(b) 防波堤 II

図-5 防波堤ケーソンにおける局部破壊の発生率と全対策費用/期待補修費用の関係 
ないと考えると, 対象ケーソン函数と対策費用 $C_{p c}$ の積 から，全対策費用 $C_{p}=n C_{p c}$ が求められる.

対象防波堤にある発生率 $P_{t}$ を与えたとき，全対策費 用 $C_{p}$ が期待補修費用 $C_{c}$ を下回る場合，予防対策が LCC 縮減の観点から有利になる。したがって, 全対策費用 $C_{p}$ が期待補修費用 $C_{c}$ を下回る発生率 $P_{t}$ を求めることで, LCC 縮減の観点から予防対策が有利な条件を検討した.

図-5 に発生率 $P_{t}$ と全対策費用/期待補修費用の関係を 示す. 四より，発生率が大きくなるほど予防対策が経済 的に有利となる。補修ケース A，Bに対して，対策ケ一 ス 2 は発生率が 10～12\%（防波堤 I），8～12％（防波堤 II）以上で予防対策が LCC 縮减の観点から有利になる. また，対策ケース 1 が有利となる発生率は，防波堤 I で 35～45\%以上，防波堤 II で 50～55\%以上となり，対策尔 一ス 3 では防波堤 I で 45～55 \%以上，防波堤 II で 25〜 30 \%以上, となった。 一方, 補修ケース C では, 発生 率 1.3〜 5\%以上でいずれの予防対策も有利になった。 こ のように，予防対策が LCC 縮減の観点から有利となる 条件は局部破壊の発生率 $P_{t}$ に強く影響され，特に堤体 滑動の有無によって補修費用は大きく変化した.

ここで，ケーソン前壁に局部破壊が生じると堤体滑動 の可能性が高まる. 堤体滑動によって消波工が沈下する と，衝撃砕波の発生が懸念される．さらには，港内側の 安全性が確保されずに二次災害の発生の恐れもある。一 般点検診断で局部破壊を発見することは容易ではないこ とを考えると，予防対策が有利となる発生率 $P_{t}$ は，補 修ケース C と比較することが望ましいと考える.

以上より，本論の検討範囲で，1.3〜 5 \%以上の発生率 $P_{t}$ が想定される防波堤では，予防対策を実施することが LCC 縮減の観点から有利といえる. 予防対策費用や補 修費用は対象防波堤の諸元等で変化することが考えられ るが，本論のように，局部破壊の発生率を考慮した期待 補修費用 $C_{c}$ と全対策費用 $C_{p}$ の比較を行うことで，LCC 縮減の観点から予防対策の優位性を示すことができる.

\section{4. おわりに}

本論は，新設の防波堤ケーソンにおいて，予防対策が LCCの観点から有利となる条件を明らかにすることを目 的とし，局部破壊が生じた実構造物を対象とした検討を 行った. 以下に本論により得られた知見を示す.

1) ケーソン前壁の予防対策として，諸元によっては鉄 筋比の増加のみで照査を満足できない防波堤があつ た。また，短繊維補強コンクリートの使用および版 厚の増加についても施工上の制約が大きいことから， 対策を併用することで合理的な断面を決定すること が必要である。

2）ケーソン前壁の予防対策として，鉄筋比の増加が最 も安価であり, 短繊維補強コンクリートの使用およ び版厚の増加はほぼ同等の費用であった。

3) 前壁に局部破壊を確認した場合, 堤体滑動が生じる 以前に補修を行うことがLCCの観点から有利である。

4) 対象ケーソンのうち1.3〜 5 \%以上に局部破壊が発生 することが想定される場合，予防対策を実施するこ とでLCC縮減の観点から有利になる.

謝辞 : 本研究の一部は, 日本学術振興会科学研究費補助 金（基盤研究(B)：23360192）によって実施いたしました. ここに記して謝意を表します.

\section{参考文献}

1）平山克也，南靖彦，奥野光洋，峰村浩治，河合弘泰，平 石哲也 : 2004年に来襲した台風による波浪災害事例，港湾 空港技術研究所資料，No.1101，2005

2) 川端雄一郎, 加藤絵万, 岩波光保 : 維持管理を考慮した 防波堤ケーソン側壁の耐衝撃設計に関する検討，港湾空 港技術研究所資料，No.1279，2013

3) 伊藤始, 岩波光保, 横田弘 : 短繊維補強コンクリートの 施工性に関する検討，港湾空港技術研究所資料，No.1087， 2004

\title{
A STUDY ON THE DESIGN METHOD OF RC CAISSONS FOR BREAKWATERS AGAINST IMPACT LOADS CONSIDERING MAINTENANCE STRATEGY
}

\section{Yuichiro KAWABATA, Ema KATO and Mitsuyasu IWANAMI}

\begin{abstract}
In breakwaters covered with wave-dissipating blocks, outer walls of the caisson may show local failure in repeated collision of the blocks. Local failure induces drainage of the filling in the caisson so that the self-weight of the caisson would be reduced. This failure of the outer wall decreases stability of the caisson against sliding and harbor calmness. The design and verification method of the caisson and the preventive measures against such accidental impact loads are necessary to be developed while they have not been established so far. When the preventive measures are implemented, it is important that the life-cycle cost (LCC) would be considered. This paper investigated the advantageous conditions of the preventive measures from the viewpoint of LCC reduction considering the ratio of failed caisson to total ones, by comparing the cost for the preventive measures and the cost for post-failure repair.
\end{abstract}

